\title{
What is neighbourhood renewal policy for?
}

\author{
Ruth Lupton* \\ University of Manchester
}

\begin{abstract}
Summary
Current policies on neighbourhood renewal in England are unrecognisable from those that were in place ten years ago. In this paper, I argue that this is not because Labour's policies failed. Indeed there is a clear picture both of absolute improvement in the poorest neighbourhoods and closing gaps with other neighbourhoods, although large gaps still remained. However, despite this, Labour changed its mind over neighbourhood renewal, losing sight of what this policy regime was for, as distinct from policies on economic regeneration. The Coalition has, in important respects, picked up the baton laid down by Gordon Brown, although not the one carried by Tony Blair. Those who would like to see a return to some of the aspects of neighbourhood renewal policy pursued in the early 2000s need, therefore, to revisit fundamental arguments about policy purposes, as well as the mechanisms by which policies are pursued.
\end{abstract}

Keywords: regeneration, renewal, neighbourhood, New Labour, Coalition.

\section{Introduction}

In England, policies on neighbourhood renewal look dramatically different in 2013 to those that were in place ten years ago. All of the major funding streams, institutions and mechanisms supporting neighbourhood renewal during the mid 2000s have been discontinued: the National Strategy for Neighbourhood Renewal, Neighbourhood Renewal Fund, Neighbourhood Renewal Unit (NRU), New Deal for Communities, Local Area Agreements, Housing Market Renewal, Area-Based Grant, and so on. Under the Coalition Government, these have not been replaced with any similar programme targeted at the poorest neighbourhoods. There is, in fact, as the House of Commons Communities and Local Government Committee (2011) pointed out, no explicit central government strategy for the improvement of conditions and opportunities in such places. Neighbourhood renewal, as we knew it under Labour, is dead.

The Coalition's policy approach focuses instead on stimulating economic growth to enable regeneration, and at the same time "helping local leaders to strengthen their communities and support people back into work" (Department for Communities and Local Government, 2011, no page number). Mechanisms include the Regional Growth Fund, reforms of the planning system, and investments in major infrastructure projects such as the high speed rail network, Crossrail and the Olympic legacy. 'City Deals' have 
been struck with the core cities, utilising a variety of mechanisms to inventivise growth, such as pooling funding streams and business rate income into single investment funds, as well as a range of new flexibilities and initiatives such as cities controlling their own 'skills budgets', and the creation of city-led business hubs. Local Enterprise Partnerships, reflecting functional economic areas, have replaced Regional Development Agencies. Clearly all of this is at a higher spatial scale than the neighbourhood. One assumes that the expectation is that benefits will trickle down. Welfare reform, particularly Universal Credit is designed to help build growth by reducing possibilities for 'dependency' on state benefits and increasing incentives to work.

At the very local level, the Coalition's approach is not to provide funding and direction from central government, but to promote action by communities themselves as part of the 'Big Society' and 'Iocalism' agendas (HM Government, 2010). One example is 'the Big Local' - a $£ 200 m$ fund from the Big Lottery to support communityled action in 150 communities over ten years. Another is the Community Organisers programme which receives government funding to recruit and train 500 community organisers.

One conclusion that might be drawn from this policy volte-face is that the policies of the previous government were resoundingly unsuccessful. In this paper, I argue that this was not the case. However, where Labour was successful it was in relation to its own initial policy objectives. Subsequently, and in a substantial way, it changed its mind over the purpose of neighbourhood renewal - such that, seen through a new policy lens, its successes could be seen as failures. These changes laid the ground for the Coalition's further withdrawal from neighbourhood renewal policy. At the current policy juncture therefore, and as the parties consider their policies in the run-up to the next election, it is worth revisiting what neighbourhood renewal is, or could be, for.

\section{What was Neighbourhood Renewal Policy for? - Labour's original account}

When Labour took over in 1997, the Single Regeneration Budget Challenge Fund (SRB) was the main policy in place to address what was increasingly being recognised as a problem of widening inequality and serious economic and social decline in Britain's worst off neighbourhoods. Labour immediately increased the political priority given to this issue, and the scale of activity and funding. Although there had been numerous previous initiatives and funds, going back to the 1960s, the New Labour government was the first to establish 'neighbourhood renewal' as a mainstream, crossdepartmental concern of central government.

Policy documents and speeches of the time indicate that the neighbourhood renewal agenda was not principally about economic regeneration, even though Labour's analysis implicated de-industrialisation as fundamental (Social Exclusion Unit, 1998). The scope of the policy was much wider - education, housing, health, environments, community capacity - and most of the spending went on these areas. It was clearly rooted in concerns about social exclusion and the multiple, interacting causes of deprivation and its rationale appeared to be social justice, in the sense of greater equity in the distribution of services, opportunities, and economic and social goods. This was given expression in the set of 'floor targets' that was established and also in the way they were described - "the social equivalent of the Minimum Wage" (NRU website) ensuring that "no longer will the poorest areas and groups go unnoticed". Poor services and conditions, it was argued, made it worse to be on a low income, and "people on low incomes should not have to suffer conditions and services that are failing and so different from what the rest of the population receives" (SEU, 
p. 68. What is neighbourhood renewal policy for?

2001: 8). A particularly strong emphasis was placed on living conditions - crime and neighbourhood environments, such that "all neighbourhoods in the country should be free of fear," and "we should not have neighbourhoods where so many people's number one priority is to move out" (SEU, 2001: 24).

The logic here was, I argue, ameliorative, not transformative - not to eliminate neighbourhood disparities nor to turn all neighbourhoods into ones that could be self sustaining without need for additional public spending, but to reduce differences between neighbourhoods such that in 10-20 years "no-one should be seriously disadvantaged by where they live" (SEU, 2001, emphasis added). Furthermore, Labour made some clear statements about the role of state and market in this endeavour. Central and local government were strongly criticised for failing to ensure territorial equity in the past (SEU, 1998) and the extensive state machinery (such as the Neighbourhood Renewal Unit, neighbourhood renewal functions in the government offices for the regions and Local Strategic Partnerships) that was established at central, regional and local level to 'mainstream' additional government spending and action in the most disadvantaged areas indicated an understanding that state interventions were not temporary - to correct short term instances of market failure but permanent, perhaps because of the inherent inability of markets to effect equitable distribution of goods, opportunities and services. Extra spending in poorer areas was an aim of policy.

\section{Considerable policy successes - in Labour's original terms}

In line with these original objectives, much of Labour's extra spending went on improvements to neighbourhood environments and services - for example about onethird of NRF money went on housing, environment and community safety initiatives, with another third on health and education (Cowen and Wilton, 2008; Amion Consulting, 2010). The result was tangible improvement of neighbourhood environmental conditions, facilities and services. 90 per cent of social housing was brought up to a decent standard. There was a fall in rates of vacant housing on unpopular estates (Fenton and Lupton, 2013). 3,500 Sure Start Childrens' Centres and over six hundred new schools were built or on the way under Building Schools for the Future, mainly targeted at the poorest neighbourhoods. 17,000 additional Police Community Support Officers were put in place, as well as neighbourhood managers and wardens.

Evidence from surveys, evaluations and case studies shows that the poorest neighbourhoods improved as places to live. Residents reported cleaner streets, better parks, reduced crime, better schools, creche and day care provision and higher satisfaction (Amion Consulting, 2010; Batty et al., 2010; Power, Willmott, and Davidson, 2011). Our own analysis of data from the British Crime Survey and English Housing Survey shows that domestic burglary rates halved between 2001 and 2009, and the relative risk of being burgled for those living in the most deprived areas also fell, as did gaps between poorer and richer neighbourhoods in the proportion of residents reporting serious problems with crime, vandalism and litter.

These improvements were not sufficient to remove differences between the poorest neighbourhoods and others. By the end of the period, the gaps in these measures of neighbourhood problems (burglary and reports of crime, vandalism and litter) were still at around 15 percentage points - comparing the poorest tenth of areas with all neighbourhoods - as was the gap in the proportion saying they were slightly or very dissatsified with their area as a place to live (English Housing Survey). Housing conditions remained unresolved in some of the worst affected neighbourhoods as 
p. 69. What is neighbourhood renewal policy for?

redevelopment schemes stalled with the financial crash in 2008. Nevertheless, an overall trend of improvement is clear.

On the whole, individual social and economic outcomes also appeared to improve and gaps closed although it is very difficult to attribute these changes to neighbourhood renewal policy per se. Our longer paper on this subject, analysing numerous adminstrative data sources (Lupton, Fenton and Fitzgerald, 2013) shows that 'worklessness' showed a steady downward trend in the highest workless neighbourhoods in England between 2000 and 2009, and the gap closed, remaining smaller even after the recession than in 2000. In education, there were dramatic reductions in numbers of schools below the performance thresholds set by government and gaps in educational performance declined. In health, gaps in the rate of deaths from cancer and circulatory diseases narrowed in absolute terms, although the overall life expectancy gap widened. Thus, overall, at a time when income inequality showed no real change, Labour presided over a modest decrease in inequalities in outcomes and neighbourhood conditions between places.

\section{Changing rationales during the 2000 s}

Despite these successes, by the early 2000s, the discourse around neighbourhood renewal had already started to change. One notable shift was the increasing emphasis being given to the importance of economic outcomes, with 'worklessness' emerging as a central term and "reducing worklessness and promoting enterprise" being given higher priority (Cabinet Office, 2004: 18). Understandings of the origins of neighbourhood economic problems were also changing, from "mass joblessness as the result of several recessions and the decline of manufacturing industry" (SEU, 2001: 17) to "low levels of economic activity" (Cabinet Office, 2004: 12). Another shift was the increasing focus on "concentrated deprivation" and on the need to introduce greater social mix in order to make communities sustainable in the long term (ODPM, 2004). This signalled a move to more transformative ambitions, embodied also in the Housing Market Renewal programme.

Under Gordon Brown as Prime Minister from 2007, the rationale for neighbourhood renewal policy was further transformed. A Treasury review (HM Treasury, CLG, and BIS, 2007), and the new Regeneration Framework to which it led (CLG, 2009) effectively subsumed 'neighbourhood renewal' into 'regeneration', which had three purposes: improving economic performance, improving rates of work and enterprise and creating sustainable places where people want to live and work and businesses want to invest (CLG, 2009).

The differences between this articulation and that of the first Blair government are profound. First it made explicit an understanding that inequalities between neighbourhoods would normally be corrected by market mechanisms, with state intervention only needed where this failed. Second, supply side problems, rather than industrial decline and uneven growth, were identified as the cause of worklessness. Third, the purpose of intervention was primarily economic efficiency, with almost no trace of any arguments around a more just distribution of neighbourhood conditions, services or opportunities. An equity rationale, where mentioned, was framed in economic terms - returning all areas to market functionality would benefit people with "barriers to full mobility" (between areas) and who were therefore "most likely to suffer disproportionately from large spatial differences in economic performance" (HM Treasury, CLG, and BIS, 2007). Fourth, in contrast to the earlier policy documents which had advocated a greater alignment of spending and services to need, on an ongoing basis, the Regeneration Framework set out a specific ambition to reduce the 
cost to the taxpayer of "subsidising rather than transforming lives." Finally, this all implied an upscaling of activity - neighbourhoods would not be transformed in economic terms by actions at the neighbourhood level.

In these terms, improvements in neighbourhood services, facilities and conditions were not ends in themselves, only (perhaps) means to an end of stronger economic performance or greater social mix, which would in turn impact on improved health, education and employment. Neighbourhood renewal's success in achieving place improvements and incremental progress in narrowing gaps between individual outcomes through state investment and management could only be seen as a failure in this more economic, market-led and transformatory vision of problem and solution. Much of the rationale for neighbourhood renewal had disappeared.

\section{The Coalition and beyond}

Seen in this light, the Coalition's policies display rather more continuity with Labour's that might seem the case if we were characterising the Labour years entirely in terms of the original, social justice-motivated, neighbourhood renewal agenda. The Coalition's 'regeneration through growth' approach follows directly from Labour's post-2007 arguments that the rationale that markets can usually be relied upon to correct large spatial inequalities, and that central government action should principally be directed at facilitating market processes. It follows the Brown government's emphasis on the city or city region as the key spatial scale for action. In some respects also, the Coalition's emphasis on the Big Society, community rights, and community action also seem to pick up some of the themes that featured in Labour's early regeneration rhetoric, but which failed to come to fruition in any meaningful way (Perrons and Skyers, 2003; Fuller and Geddes, 2008; Imrie and Raco, 2003).

What the Coalition has dropped, of course, is any central direction and most of the central funding for regeneration work, as well as any attempt to mandate local authorities to pay attention to spatial disparities and monitor their success in doing so. It is hard to determine the extent to which this approach is borne out of the perceived necessity of deleting funding streams, a lack of concern with the issue of spatial inequalities on the grounds that they are a necessary and probably temporary feature of efficient markets, or the Coalition's ideological commitment to reduce the role of the central state on the grounds that it stifles entrepreneurialism and responsibility and fosters dependency. A future government might take a different approach to funding and organising 'regeneration', with a stronger central hand, or more central funding to support bottom-up activity led by local organisations. There is a question about how well embedded the principles of greater territorial equity and the mechanisms for its delivery have become at local level, and how much they need central steering.

It seems to me, however, that these are questions of how action is organised, not what it is for. This is not to underplay their importance - these are critical issues about relationships between citizenry, markets, and different levels of the state. My point, illuminated I hope by the history set out in this paper, is that those who are dissatisfied with what is happening now and would like to see a return to the policies of Labour's early years when central government took responsibility for spatial inequalities and conditions in the poorest neighbourhoods, and supported funding and action at the neighbourhood scale, need also to return to a different line of argument - that neighbourhood renewal is different from economic regeneration and has an independent rationale. This I would put, as Labour put it in 1997, is that large gaps in living conditions, or conditions below a threshold of acceptability are socially unjust, and that economic growth tends to be unequal and spatially uneven - thus not 


\section{p. 71. What is neighbourhood renewal policy for?}

delivering the equal and sustainable neighbourhoods hoped for and creating a continual job for neighbourhood-level social welfare programmes. These arguments are not currently being articulated by any political party in England. Looking backwards even over this short period of time reminds us of the possibility of a wider debate about the policy directions that might be followed, even in an age of localism and austerity.

\section{Notes}

1 http://webarchive.nationalarchives.gov.uk/20060530091128/http://neighbour hood.gov.uk/page.asp?id=585 Accessed 9th March 2012

\section{Acknowledgements}

The analysis of policy and outcomes on which this paper is based is drawn from a fuller working paper (Lupton, Fenton and Fitzgerald, 2013) to which Alex Fenton and Amanda Fitzgerald were substantial contributors. The research was funded by the Nuffield Foundation, Joseph Rowntree Foundation and Trust for London. The views expressed in this paper, and any errors or omissions, are my own.

* Correspondence Address: Ruth Lupton, Manchester Institute of Education, School of Environment, Education and Development, University of Manchester, A5.12 Ellen Wilkinson Building, Oxford Road, Manchester M13 9PL. Email: ruth.lupton@manchester.ac.uk

\section{Bibliography}

Amion Consulting (2010) Evaluation of the National Strategy for Neighbourhood Renewal. Final Report: Summary. London: Department for Communities and Local Government.

Batty, E., Beatty, C., Foden, M., Lawless, P., Pearson, S. and Wilson, I. (2010) The New Deal for Communities Experience: A Final Assessment. Volume 7. New Deal for Communities Evaluation Final Report. London: Communities and Local Government.

Bashir, N. and Flint, J. (2010) Residents' Perceptions of Neighbourhood Change and Its Impacts. Research Paper No 2. Living Through Change in Challenging Neighbourhoods. Sheffield: CRESR, Sheffield Hallam University. http://research.shu.ac.uk/cresr/living-through-change/documents /RP2_NeighbourhoodChange.pdf

Cabinet Office (2004) Improving the Prospects of People Living in Areas of Multiple Deprivation in England. London: Cabinet Office.

CLG (2009) Transforming Places; Changing Lives A Framework for Regeneration. London: Communities and Local Government.

Cowen, G. and Wilton, M. (2008) Impacts and Outcomes of the Neighbourhood Renewal Fund. London: Communities and Local Government. http://www.communities.gov.uk/publications/communities/nrfimpactsoutcomes.

CLG (2011) Regeneration to Enable Growth: What the Government Is Doing in Support of Community-led Regeneration. London: Communities and Local Government. 
Fenton, A. and Lupton, R. (2013) Low-demand Housing and Unpopular Neighbourhoods Under Labour. Social Policy in a Cold Climate Research Note RN006. London: CASE, LSE. http://sticerd.Ise.ac.uk/dps/case/spcc/rn006.pdf.

Fuller, C. and Geddes, M. (2008) Urban governance under neoliberalism: New Labour and the restructuring of state-space. Antipode, 40, 2, 252-282.

HM Government (2010) Decentralisation and the Localism Bill: an essential guide. London: Department for Communities and Local Government.

HM Treasury, CLG, and BIS (2007) Review of Sub-national Economic Development and Regeneration. London: HM Treasury.

House of Commons Communities and Local Government Committee (2011) Regeneration: Sixth Report of Session 2010-12. HC 1014. London: The Stationery Office.

Imrie, R. and Raco, M. (2003) Community and the changing nature of urban policy, In: Urban Renaissance? New Labour, community and urban policy. Bristol: The Policy Press.

Lupton, R., Fenton, A. and Fitzgerald, A. (2013) Labour's Record on Neighbourhood Renewal in England: Policy, Spending and Outcomes 1997-2010. Social Policy in a Cold Climate Working Paper WP06. London: CASE, LSE.

ODPM (2004) Annual Report 2004. London: ODPM.

Perrons, D. and Skyers, S. (2003) Empowerment through participation? Conceptual explorations and a case study. International Journal of Urban and Regional Research, 27, 2, 265-285.

Power, A., Willmott, H. and Davidson, R. (2011) Family Futures: Children and Poverty in Urban Neighbourhoods. Bristol: The Policy Press.

SEU (2001) A New Commitment to Neighbourhood Renewal: National Strategy Action Plan. London: Social Exclusion Unit.

SEU (1998) Bringing Britain Together: A National Strategy for Neighbourhood Renewal. CM 4045. London: Social Exclusion Unit. 